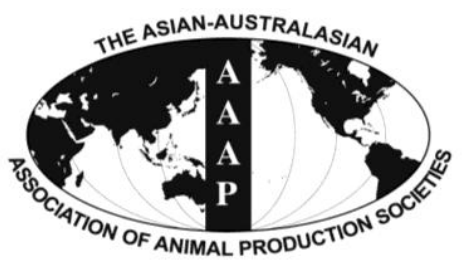

Asian Australas. J. Anim. Sci.

Vol. 26, No. 7 : 1021-1029 July 2013

http://dx.doi.org/10.5713/ajas.2013.13012

www.ajas.info

pISSN 1011-2367 elSSN 1976-5517

\title{
Effects of Dietary Chromium Methionine on Growth Performance, Carcass Composition, Meat Colour and Expression of the Colour-related Gene Myoglobin of Growing-finishing Pigs
}

\author{
Y. S. Li $^{1}$, N. H. Zhu ${ }^{2,3}$, P. P. Niu ${ }^{1}$, F. X. Shi ${ }^{1}$, C. L. Hughes ${ }^{4}$, G. X. Tian ${ }^{5}$, and R. H. Huang ${ }^{1, *}$ \\ ${ }^{1}$ College of Animal Science and Technology, Nanjing Agricultural University, Nanjing, 210095, China
}

\begin{abstract}
To investigate the effect of dietary chromium $(\mathrm{Cr})$ as $\mathrm{Cr}$ methionine (CrMet) on growth performance, carcass traits, pork quality, meat colour and expression of meat colour-related genes in growing-finishing pigs, 189 crossbred Duroc $\times$ (Landrace $\times$ Yorkshire) growing-finishing pigs (male, castrated, average initial BW $74.58 \pm 1.52 \mathrm{~kg}$ ) were selected and randomly allocated into four groups. Dietary treatments per kg of feed were as follows: 0 (CT), $0.3 \mathrm{mg} / \mathrm{kg}$ (T1), $0.6 \mathrm{mg} / \mathrm{kg}$ (T2) and $0.9 \mathrm{mg} / \mathrm{kg}$ (T3) Cr (in the form of CrMet; as-fed basis), and each treatment was replicated five times with 8 to 10 pigs per replicate pen. During the $28 \mathrm{~d}$ of the experiment, both the ADG and the ADFI increased linearly $(\mathrm{p}<0.05)$ as the level of dietary $\mathrm{Cr}$ increased. The F/G ratio decreased linearly $(\mathrm{p}<0.05)$. As dietary $\mathrm{Cr}$ increased, loin muscle areas (linear, $\mathrm{p}=0.013$ ) and average backfat thickness (linear, $\mathrm{p}=0.072$ ) decreased. Shear force (linear, $\mathrm{p}=0.070$ ) and Commission Internationale de I'Éclairage (CIE) redness (quadratic, $\mathrm{p}=0.028$ ) were increased. In addition, CIE Lightness (quadratic, $\mathrm{p}=0.053$ ) were decreased as dietary $\mathrm{Cr}$ increased. As dietary $\mathrm{Cr}$ increased, total myglobin $(\mathrm{Mb})$ content (quadratic, $\mathrm{p}=0.015$ ) and the $m b$ mRNA levels (quadratic, $\mathrm{p}=0.046$ ) in longissimus muscles of pigs were up-regulated. In conclusion, supplementation of dietary $\mathrm{Cr}$ improved growth and meat colour, but increased shear force and decreased IMF reduced palatability of longissimus muscles. Moreover, the increasing total Mb content and $m b$ mRNA levels indicated that CrMet dietary supplementation may improve meat colour via up-regulating expression of the $m b$ gene. (Key Words: Growing-finishing Pigs, Chromium Methionine, Meat Colour, Myoglobin)
\end{abstract}

\section{INTRODUCTION}

Chromium $(\mathrm{Cr})$ is a trace mineral involved in the metabolism of carbohydrates, lipids, proteins and nucleic acids. Trivalent $\mathrm{Cr}$ plays important roles in human diet and medicine, e.g. regulating glucose and lipid metabolism in humans and laboratory animals (Mertz, 1993; Haldar et al., 2009; Krzysik et al., 2011). A recent study also reported that maternal $\mathrm{Cr}$ restriction significantly decreased the percent of lean body mass and fat-free mass in rat offspring

\footnotetext{
* Corresponding Author: R. H. Huang. Tel: $+86(0) 25-84395362$, Fax: +86(0)25-84395314, E-mail: rhhuang@ @jau.edu.cn

${ }^{2}$ College of Animal Science and Technology, Jiangxi Agricultural University, Nanchang, 330045, China.

${ }^{3}$ Changsha Hing Ka Biological Engineering Co., Ltd., Changsha, 410011, China.

${ }^{4}$ Department of Mathematics, North Carolina State University, Raleigh, 27695, USA.

${ }^{5}$ Changzhou Yongkang Agricultural and Animal Husbandry Technology Co., Ltd., Changzhou, 213000, China.

Submitted Jan. 5, 2013; Accepted Mar. 6, 2013; Revised Mar. 27, 2013
}

(Padmavathi et al., 2010). The effects of $\mathrm{Cr}$ have been investigated for potential use as feed additives in animal production. However, the results were not always consistent; e.g. dietary $\mathrm{Cr}$ propionate (CrProp) supplementation was reported to decrease 10th-rib backfat thickness in crossbred Yorkshire gilts (Jackson et al., 2009), but in another report the 10th-rib backfat thickness was not affected in the same crossbred gilts fed the same dose CrProp (Matthews et al., 2005). Previous examinations of $\mathrm{Cr}$ supplementation of swine diets have been primarily conducted with $\mathrm{Cr}$ picolinate ( $\mathrm{CrPic}), \mathrm{Cr}$ nicotinate ( $\mathrm{CrNic}$ ), CrProp or $\mathrm{Cr}$ chloride $\left(\mathrm{CrCl}_{3}\right)$, whereas investigations using $\mathrm{Cr}$ methionine (CrMet) are less common. Moreover, chromium methionine chelate could directly cross the intestinal cell membrane and be metabolized without any prior digestion due to being chelated with amino acids (Ohh and Lee, 2005). Based on these reasons above, bioavailability of CrMet may be higher than those of other organic chromium compounds.

Meat colour, one of the most important factors in 
determining consumer choice (Mancini and Hunt, 2005; Hoek et al., 2011), is the result of complex interactions among animal genetics, antemortem and postmortem conditions, fundamental muscle chemistry and many factors related to meat processing, packaging, distribution, storage, display and final preparation for consumption (Hunt et al., 2004; Gandolfi et al., 2011). Recent studies have shown that dietary $\mathrm{Cr}$ supplementation is increasingly well recognized as a potential means of improving meat colour. There were a series of experiments in which various levels of $\mathrm{Cr}$ were fed to pigs, and reported that the subjective colour score was increased by $16.5 \%$ by adding $0.2 \mathrm{mg} / \mathrm{kg} \mathrm{Cr}$ as CrProp (Shelton et al., 2003). Additionally, different levels of total muscular pigment in the ribeye area were significantly improved $(\mathrm{p}<0.05)$ in growing-finishing pigs fed $\mathrm{CrPic}$ (Zhang et al., 2011). Furthermore, the research of Matthews et al. (2005) indicated that CIE L*, $a^{*}, b^{*}$ of the loin muscle were not affected $(\mathrm{p}<0.62$ to 0.99$)$ by CrProp. Myoglobin $(\mathrm{Mb})$, a water-soluble protein, is commonly found in three forms, oxymyoglobin, deoxymyoglobin and metmyoglobin, the relative proportions of which determine the colour of fresh meat (Wallace et al., 1982). However, few studies have examined the effects of supplementation with CrMet on the related gene $m b$.

With increasing focus on meat quality in the swine industry and lacking the published data regarding the potential effects of $\mathrm{Cr}$ on meat quality, particularly meat colour, clearly defining the effects of $\mathrm{Cr}$ on pork quality is necessary. Thus, the purpose of this study was to evaluate the effects of CrMet as $\mathrm{Cr}$ source on growth, carcass composition of growing-finishing pigs and on the meat quality of the pork by focusing on the expression of a gene related to meat colour. We hypothesized that $\mathrm{Cr}$ supplementation might improve growth, carcass traits and meat quality, and induce some alterations in meat colour via the $m b$ gene expression in growing-finishing pig fed with CrMet.

\section{MATERIALS AND METHODS}

\section{Animal selection and allotment}

In total, 189 crossbred Duroc $\times($ Landrace $\times$ Yorkshire $)$ growing-finishing pigs (male, castrated, average initial BW $74.58 \pm 1.52 \mathrm{~kg}$ were selected from a breeding pig farm of Changzhou Yongkang Agricultural and Animal Husbandry Technology Co., Ltd (Jintan, Jiangsu, China) where the purebred Yorkshire, Landrace and Duroc had already been in closed bred for nearly $10 \mathrm{yrs}$. The pigs were randomly divided into four groups. The experimental pigs were housed in a curtain-sided finishing piggery and raised in pens $(2.7 \mathrm{~m} \times 3.0 \mathrm{~m})$ with a concrete-slotted floor in a single row confinement house with a 1.2-m-wide Northern-alley. Each treatment group had five pens with 8 to10 animals in each pen. The pigs had free access to food, as well as water from nipple drinkers within a transverse aeration-cooling system. The house received natural light for approximately $14 \mathrm{~h}$ daily. The ambient temperature of the inner house ranged from $16.1 \pm 2.6^{\circ} \mathrm{C}(06: 00$ to $07: 00 \mathrm{~h})$ to $10.7 \pm 3.4^{\circ} \mathrm{C}$ (14:00 to $15: 00 \mathrm{~h}$ ) with $18.5 \pm 3.5^{\circ} \mathrm{C}$ on average. The relative humidity ranged from $63.9 \pm 5.6 \%(06: 00$ to $07: 00 \mathrm{~h})$ to 67.4 $\pm 7.5 \%$ (14:00 to $15: 00 \mathrm{~h}$ ) with $64.9 \% \pm 6.49 \%$ on average. No vaccination was administered during the experimental period according to the immunization rules of the experimental farm. Faeces were cleaned from pens twice. At the end of the trial, growth performance was determined from 189 pigs, and five pigs per treatment (one pig per pen) were selected by having a body weight at the median for the group and used to evaluate carcass traits, pork quality, total myoglobin $(\mathrm{Mb})$ content and the relative quantity of the $\mathrm{Mb}$ gene $(\mathrm{mb})$ mRNA. The study and animal care protocols followed the guidelines from the Laboratory of Animal Management Association of Nanjing Agricultural University.

The experimental pigs were allotted to four dietary treatments on the basis of weight, and ancestry was equalized across treatments in a randomized complete block design. Pigs in the control group were fed a basal diet (control treatment, CT), whereas the experimental groups were fed basal diets supplemented with $\mathrm{Cr}$ in the form of CrMet (Hing Ka Bio-Engineering Co. Ltd) representing the following dietary proportions: $0.30 \mathrm{mg} / \mathrm{kg} \mathrm{Cr}$ (treatment 1 , T1), $0.60 \mathrm{mg} / \mathrm{kg} \mathrm{Cr}$ (treatment 2, T2) and $0.90 \mathrm{mg} / \mathrm{kg} \mathrm{Cr}$ (treatment 3, T3). The diet met or exceeded NRC (1998) recommendations for nutrients except digestible energy and was analyzed to provide $15.73 \% \mathrm{CP}, 0.71 \%$ calcium, $0.58 \%$ phosphorus, $0.80 \%$ lysine and was calculated to provide digestible energy concentration of $3,151 \mathrm{kcal} / \mathrm{kg}$. Basal diet composition and nutrient contents are shown in Table 1. Nutritional analysis showed the content of methionine and cysteine in the basal diet was $0.63 \%$, which is higher than that of requirements for 50 to $120 \mathrm{~kg}$ growing pigs (NRC, 1998). Thus, a modest methionine in CrMet could not be expected to have an effect. Diets were mixed and sampled weekly. Feed samples from each treatment were collected and analyzed for dry matter, N, Ca and P according to the Association of Official Analytical Chemists procedures (AOAC, 1997).

\section{Growth performance}

Surplus feed remaining in the feeders of each pen (replicate) was cleared away and weighed daily. Feed intake was calculated and recorded daily. Pre-feeding body weight of each pig was recorded individually at the beginning of the experiment to obtain the initial body weight, and at the end of the finishing period to get the terminal weight. Average daily gain (ADG), average daily feed intake 
Table 1. Ingredient composition and nutrient contents of basal diets for experimental growing-finishing pigs

\begin{tabular}{|c|c|}
\hline Items & Amount (\%) \\
\hline \multicolumn{2}{|l|}{ Ingredient } \\
\hline Corn & 67.86 \\
\hline Soybean meal & 15.25 \\
\hline Wheat bran & 14.14 \\
\hline Monocalcium phosphate & 0.63 \\
\hline Limestone & 0.84 \\
\hline Salt & 0.10 \\
\hline L-lysine $\cdot \mathrm{HCl}$ & 0.13 \\
\hline Vitamin and mineral premix ${ }^{1}$ & 1.05 \\
\hline \multicolumn{2}{|l|}{ Nutrition composition } \\
\hline Digestible energy (kcal/kg) & 3,151 \\
\hline Crude protein & 15.73 \\
\hline $\mathrm{Ca}$ & 0.71 \\
\hline $\mathrm{P}$ & 0.58 \\
\hline Lysine & 0.80 \\
\hline Methionine and cysteine & 0.63 \\
\hline \multicolumn{2}{|c|}{$\begin{array}{l}{ }^{1} \text { Vitamin premix provided per kilogram of diet: vitamin } \mathrm{A}, 10,000 \mathrm{IU} \text {; } \\
\text { vitamin } \mathrm{D}_{3}, 1,400 \mathrm{IU} \text {; vitamin E, } 400 \mathrm{mg} \text {; vitamin } \mathrm{K}_{3}, 60 \mathrm{mg} \text {; vitamin } \mathrm{B}_{1} \text {, } \\
30 \mathrm{mg} \text {; vitamin } \mathrm{B}_{2}, 110 \mathrm{mg} \text {; vitamin } \mathrm{B}_{6}, 80 \mathrm{mg} \text {; vitamin } \mathrm{B}_{12}, 0.4 \mathrm{mg} \text {; } \\
\text { niacin, } 450 \mathrm{mg} \text {; Ca-D-pantothenic acid, } 170 \mathrm{mg} \text {; folic acid, } 11 \mathrm{mg} \text {; }- \\
\text { biotin, } 0.8 \mathrm{mg} \text {; and choline chloride, } 10 \mathrm{~g} \text {; Mn (manganese sulphate), } 850 \\
\mathrm{mg} \text {; Fe (ferrous sulphate), } 1,500 \mathrm{mg} \text {; } \mathrm{Zn} \text { (zinc sulphate), } 1,500 \mathrm{mg} \text {; } \\
\text { Copper (copper sulphate), } 150 \mathrm{mg} \text {; (ethylene-diamine dihydriodide), } 7 \\
\mathrm{mg} \text {; Selenium (sodium selenite), } 0.25 \mathrm{mg} \text {. }\end{array}$} \\
\hline
\end{tabular}

(ADFI), and feed gain ratio $(\mathrm{F} / \mathrm{G})$ were then calculated. The experimental period lasted approximately $28 \mathrm{~d}$.

Any episodes of diarrhoea or death were recorded daily and compiled across the study. Three inspections were performed each day, in the early morning before cleaning, during feeding and after feeding. If watery faeces were found on the floor, the anus of each pig in the pen would be checked and judged. An episode of diarrhoea was accounted if the faeces was watery or was adherent to the anus. The incidence of diarrhoea was calculated as follows: incidence of diarrhoea $(\%)=($ total head of diarrhoea pigs/number of experimental pigs) $\times 100 \%$. When death occurred, the BW of the dead pig was recorded.

\section{Carcass evaluation}

At a mean block weight of $100 \mathrm{~kg}, 20$ pigs (one pig per pen selected on the basis of body weight near the mean group body weight) were commercially slaughtered by conventional methods. Carcasses were split along the dorsal midline, weighed, and chilled in $2{ }^{\circ} \mathrm{C}$ for $24 \mathrm{~h}$ (Gandolfi et al., 2011). Loin muscle area between the 12th and 13th sternal ribs was determined, and average backfat thickness (ABT) was measured at three locations (first rib, last rib and last lumbar vertebrate). All carcass measurements were taken from the left side and determined using the equations and procedures of National Pork Producers Council (NPPC,
2000).

\section{Pork quality evaluation}

Forty-five-minute $\mathrm{pH}\left(\mathrm{pH}_{1}\right)$ was determined in loin between the 10th and 11th ribs with a hand-held $\mathrm{pH}$ meter (model HI9025, HANNA instruments, Portugal). After collection of all carcass data, loin sections from the 10th to 14th ribs and from 1st to 2nd lumbar were collected respectively. The 12th-rib chop was used to determine water binding capacity (WBC). Total percent of loin water content was measured by oven at $100^{\circ} \mathrm{C}$ for $16 \mathrm{~h}$ (AOAC, 1997). A $35-\mathrm{kg}$ pressure was vertically exerted on the surface of the loin sample collected by a standard circle sampler (diameter, $25.23 \mathrm{~mm}$; thickness, $10 \mathrm{~mm}$ ) for $5 \mathrm{~min}$ with a soil compression device (WZ-2, Nanjing Ningxi Soil Instrument Corporation, Ltd, Nanjing, China). Initial and final weights of the loin sample were obtained before and after pressing. WBC was calculated as follows: 1-((initial loin weight (g)final loin weight $(\mathrm{g})) /($ initial loin weight $(\mathrm{g}) \times$ total percent loin water content) $\times 100 \%$. The loin section from 1 st to 2 nd lumbars was used to determine shear force (SF) using a $\mathrm{SF}$ tester (XL1155, XIELI Technology Corporation, Ltd, Qinhuangdao, China) with a load cell capacity of $50 \mathrm{~kg}$ and fitted with a Warner-Bratzler shearing device (Honikel, 1998). Six 1.27-diameter cores were removed from the lumbars parallel to the longitudinal orientation of muscle fibers. Each core was sheared perpendicular to the long axis of the core for SF determination. Immediately after the collection of the loin, Commission Internationale de I'Éclairage (CIE) $L^{*}, a^{*}$ and $b^{*}$ values were obtained from three orientations on the last-rib loin interface using a Minolta spectrophotometer (model CR-10; Minolta Corp., Ramsey, NJ) (Mason et al., 2005). Two minced loin meat samples of approximately $20 \mathrm{~g}$ divided from the loin of the 14th rib were used to determine intramuscular fat percentage (IMF) using the modified Soxhlet method (AOAC, 1997).

\section{Total Mb content analysis}

After the collection of the loin section, approximately 5 $\mathrm{g}$ longissmus muscle sample from the 14th rib were collected and stored at $-20^{\circ} \mathrm{C}$ for subsequent $\mathrm{Mb}$ content analysIs. $\mathrm{Mb}$ were extracted in duplicate from longissimus muscle samples by using Tris-EDTA buffer ( $3 \mathrm{mM} / \mathrm{L} \mathrm{MgCl}_{2}$, $5 \mathrm{mM} / \mathrm{L}$ EDTA, $75 \mathrm{mM} / \mathrm{L}$ Tris, $\left.\mathrm{pH} 7.2,20^{\circ} \mathrm{C}\right)$. The solutions containing $\mathrm{Mb}$ were obtained by centrifugation of the longissimus muscle at $10,000 \times g$ and $4^{\circ} \mathrm{C}$ for $10 \mathrm{~min}$, and total $\mathrm{Mb}$ concentration was assayed at OD $525 \mathrm{~nm}$ (Krzywicki, 1982). The total Mb content was expressed as mg Mb per gram wet sample.

\section{RNA isolation and quantitative real-time PCR}

Within 30 min following exsanguination, approximately 
$2 \mathrm{~g}$ longissmus samples were removed from the 14th rib of each carcass, frozen in liquid nitrogen and stored at $-80^{\circ} \mathrm{C}$ for subsequent RNA analysis. Total tissue RNA was extracted from longissimus muscle using the TRIzol reagent (TIAN GEN Biotech Co. Ltd., Beijing, China) according to the manufacturer's instruction. The RNA was resuspended in diethyl pyrocarbonate-treated water and quantified by measuring optical density (OD) at $260 \mathrm{~nm}$ (NANODROP1000, Thermo, Shanghai, China). The purity of the RNA preparation was estimated using the OD260/280 ratio, and RNA integrity was verified by $1.5 \%$ agarose, $2.2 \mathrm{M}$ formaldehyde gel electrophoresis. All RNA samples used in quantitative real-time PCR analysis exhibited OD260/280 ratios >1.8. Strand cDNA was synthesized by reverse transcription of $2 \mu \mathrm{g}$ of total RNA using TIANScript (TIAN GEN Biotech Co. Ltd., Beijing, China) to obtain first-strand complementary DNA. The cDNA was amplified using a PCR optimization kit (TIAN GEN Biotech Co. Ltd., Beijing, China). Primers for quantitative real-time PCR amplification of the glyceraldehyde-3-phosphate dehydrogenase gene (gapdh) and $m b$ were designed using Primer V5 software. Gene-specific primers for gapdh (forward, 5'-GGACTCATGACCACGGTCCA-3'; reverse, 5'-TCAGATCCACAACCGACACGT-3'; GenBank sequence No. U48832) and $m b$ (forward, 5'-ATGCCACCAA GCACAAG-3'; reverse, 5'-CAAACCCTACAGCTACA GGA-3'; GenBank sequence No. M14433.1) were synthesized by Invitrogen Co. (Shanghai, China). The expression levels of genes were detected using an ABI 7300 Mastercycler (Applied Biosystems, USA) with qPCR mix, SYBR Premix Ex TaqTM (Takara Biotechology Co., Ltd., Dalian, China) according to the manufacturer's instructions. A water and a no-RT as controls were included to detect possible contamination in reaction. Each cDNA generated by reverse transcription was used as a temple for PCR using a $20 \mu \mathrm{l}$ reaction mixture, in triplicate. The real-time PCR cycling conditions used were $95^{\circ} \mathrm{C}$ for $3 \mathrm{~min}$, followed by 40 cycles at $95^{\circ} \mathrm{C}$ for $15 \mathrm{~s}$ and $57^{\circ} \mathrm{C}$ for $15 \mathrm{~s}$, then 1 cycle at $72^{\circ} \mathrm{C}$ for $30 \mathrm{~s}$. The amplification efficiency for two genes were investigated by gradient dilution of longissimus muscle cDNA and found to be more than $90 \%$. The values were normalized using gapdh as an endogenous standard. The relative concentration of mRNA was calculated using the $2^{-\Delta \Delta \mathrm{Ct}}$ method (Livak and Schmittgen, 2001). The amplified product was applied to a $2 \%$ agarose/ethidium bromide gel for electrophoresis.

\section{Statistical analysis}

Data were analyzed by univariate analysis of variance procedures using the general linear model of SPSS version 16.0 (Statistical Product and Service Solutions Incorporation, 2008), where a polynomial contrast was constructed to determine linear and quadratic effects of increased dietary $\mathrm{Cr}$ levels. Carcass data were analyzed with final body weight as a covariate. The pen of pigs served as the experimental unit for all data. The experimental data were presented as means.

\section{RESULTS}

\section{Growth performance analysis}

The duration of the trial was $28 \mathrm{~d}$. One pig from the control treatment was removed from the study on $\mathrm{d} 12$ due to extreme weakness of its forequarters. Another pig from the $0.9 \mathrm{mg} / \mathrm{kg} \mathrm{Cr}$ treatment exhibited a vomiting reaction on d 26 without any previous indication of problems. No pigs fed the $0.3 \mathrm{mg} / \mathrm{kg} \mathrm{Cr}$ or $0.6 \mathrm{mg} / \mathrm{kg} \mathrm{Cr}$ diet were removed from the experiment and none of pigs subjected to the dietary treatments were treated for any type of illness. For each pen, total feed intake was recorded daily and average value of the individual feed intake could be obtained by dividing total feed intake by pig number in each pen. The effects of increasing the level of dietary $\mathrm{Cr}$ on growth performance of the experimental pigs are shown in Table 2. A quadratic effect of dietary $\mathrm{Cr}$ supplementation levels on final body weight was detected $(\mathrm{p}=0.037)$. Feeding increasing levels of dietary $\mathrm{Cr}$ affected the ADG, ADFI and F/G across the whole $28 \mathrm{~d}$ experiment. A linear effect of dietary Cr levels on ADG ( $p=0.044)$, ADFI $(p=0.034)$ and $\mathrm{F} / \mathrm{G}$ ratio $(\mathrm{p}=0.005)$ was detected with the increased levels of dietary $\mathrm{Cr}$.

Table 2. Effects of chromium supplementation on the growth performance of the growing-finishing pigs during the $28 \mathrm{~d}$ experiment ${ }^{1}$

\begin{tabular}{|c|c|c|c|c|c|c|c|}
\hline \multirow{2}{*}{ Item } & \multicolumn{4}{|c|}{ Cr level (mg/kg) } & \multirow{2}{*}{$\mathrm{SEM}^{2}$} & \multicolumn{2}{|c|}{$\mathrm{p}$-value } \\
\hline & 0 & 0.3 & 0.6 & 0.9 & & Linear & Quadratic \\
\hline$\overline{\mathrm{IBW}}(\mathrm{kg})$ & 75.79 & 74.82 & 73.44 & 74.81 & 0.48 & 0.504 & 0.202 \\
\hline FBW (kg) & 99.74 & 99.74 & 101.23 & 103.68 & 1.86 & 0.076 & 0.037 \\
\hline ADG (g) & 855.4 & 890.1 & 992.6 & $1,031.1$ & 41.5 & 0.044 & 0.282 \\
\hline ADFI (kg) & 3.002 & 3.177 & 3.613 & 3.794 & 0.18 & 0.034 & 0.252 \\
\hline $\mathrm{F} / \mathrm{G}$ & 3.51 & 3.57 & 3.64 & 3.68 & 0.04 & 0.005 & 0.069 \\
\hline
\end{tabular}

${ }^{1} \mathrm{IBW}=$ Initial body weight; FBW = Final body weight; ADG = Average daily gain; ADFI = Average daily food intake; F/G = Food gain ratio. Pen was considered as an experimental unit for growth performance ( $\mathrm{n}=8$ to 10$)$.

${ }^{2}$ Standard error of the mean. 
Table 3. Effects of dietary chromium methione on carcass composition of finishing pigs ${ }^{1}$

\begin{tabular}{|c|c|c|c|c|c|c|c|}
\hline \multirow{2}{*}{ Item } & \multicolumn{4}{|c|}{ Cr level $(\mathrm{mg} / \mathrm{kg})$} & \multirow{2}{*}{ SEM $^{2}$} & \multicolumn{2}{|c|}{ p-value } \\
\hline & 0 & 0.3 & 0.6 & 0.9 & & Linear & Quadratic \\
\hline $\mathrm{DP}(\%)$ & 73.68 & 72.97 & 73.90 & 73.58 & 0.40 & 0.636 & 0.843 \\
\hline $\mathrm{ABT}(\mathrm{cm})$ & 2.46 & 2.08 & 1.99 & 1.90 & 0.25 & 0.072 & 0.152 \\
\hline $\operatorname{LMA}\left(\mathrm{cm}^{2}\right)$ & 34.21 & 36.69 & 38.72 & 38.68 & 2.13 & 0.013 & 0.158 \\
\hline LMP (\%) & 63.28 & 65.46 & 67.83 & 67.92 & 2.21 & 0.122 & 0.133 \\
\hline
\end{tabular}

${ }^{1} \mathrm{DP}=$ Dressing percentage; ABT = Average backfat thickness of the first and last rib and last lumbar fat depths; LMA = Loin muscle area; LMP = Lean meat percentage. Pen was considered as an experimental unit. Values were presented as means $(n=5)$.

${ }^{2}$ Standard error of the mean.

\section{Carcass composition analysis}

Carcass composition parameters (dressing percentage, $\mathrm{ABT}$, loin muscle area and lean meat percentage) are shown in Table 3. As levels of dietary $\mathrm{Cr}$ increased, loin muscle area increased linearly $(\mathrm{p}=0.013)$, while ABT decreased linearly $(\mathrm{p}=0.072)$.

\section{Pork quality analysis}

Pork quality parameters of $\mathrm{pH}_{1}$, WBC, SF, IMF, CIE L*, CIE $\mathrm{a}^{*}$ and CIE $\mathrm{b}^{*}$ are shown in Table 4 . When the dietary $\mathrm{Cr}$ supplementation was increased from $0 \mathrm{mg} / \mathrm{kg}$ to 0.9 $\mathrm{mg} / \mathrm{kg}$, SF tended to increase in a linear response $(\mathrm{p}=$ $0.070)$ and CIE $a^{*}$ tended to increase in a quadratic response ( $\mathrm{p}=0.028$ ), while CIE $\mathrm{L}^{*}$ tended to decrease in a quadratic response $(\mathrm{p}=0.053)$.

\section{The total Mb content and $m b$ expression in longissimus} muscle

Table 4 shows the total $\mathrm{Mb}$ concentrations among different treatments in the longissimus muscle. A quadratic effect of dietary $\mathrm{Cr}$ supplementation levels on total $\mathrm{Mb}$ content was detected $(\mathrm{p}=0.015)$. The effect of dietary $\mathrm{Cr}$ supplementation on the expression of $m b$ in longissimus muscle was investigated using quantitative real-time PCR
(Table 4). A quadratic effect of dietary $\mathrm{Cr}$ supplementation levels on $m b$ mRNA levels was detected ( $\mathrm{p}=0.046)$.

\section{DISCUSSION}

\section{The effect of dietary CrMet on growth performance}

Recent studies showed that dietary $\mathrm{Cr}$ supplementation affected protein (muscle mass) and fat deposition (Wang and Xu, 2004; Jackson et al., 2009). It has been suggested that there is a muscle deposition peak of pigs near 60 to 90 $\mathrm{kg}$ body weight and thereafter fat deposition becomes the main part of the body weight gain (Gu et al., 1991; Wagner et al., 1999). In our study, growing-finishing pigs whose initial weight was approximately $75 \mathrm{~kg}$ were selected to investigate the effect of dietary $\mathrm{Cr}$ as CrMet.

The present results showed that increasing dietary $\mathrm{Cr}$ as CrMet significantly increased ADG, ADFI and F/G in a linear fashion $(\mathrm{p}<0.05)$, indicating that dietary $\mathrm{Cr}$ supplementation does affect $A D G, A D F I$ and $F / G$ in growing-finishing pigs as body weights grow from 75 to $100 \mathrm{~kg}$ over about one month. Increased levels of $\mathrm{Cr}$ supplementation increased AFDI significantly, which resulted in increased ADG. However, the efficiency of feed utilization of growing-finishing pigs decreased linearly $(p=$

Table 4. Effects of dietary chromium methione on pork qualities, the total myoglobin $(\mathrm{Mb})$ content and the relative $m b$ mRNA level in the longissimus muscle of growing-finishing pigs ${ }^{1}$

\begin{tabular}{|c|c|c|c|c|c|c|c|}
\hline \multirow{2}{*}{ Item } & \multicolumn{4}{|c|}{ Cr level $(\mathrm{mg} / \mathrm{kg})$} & \multirow{2}{*}{ SEM $^{2}$} & \multicolumn{2}{|c|}{$\mathrm{p}$-value } \\
\hline & 0 & 0.3 & 0.6 & 0.9 & & Linear & Quadratic \\
\hline $\mathrm{pH}_{1}(\%)$ & 6.21 & 6.20 & 6.21 & 6.28 & 0.04 & 0.232 & 0.140 \\
\hline WBC (\%) & 68.87 & 68.85 & 68.82 & 68.86 & 0.02 & 0.641 & 0.478 \\
\hline $\mathrm{SF}\left(\mathrm{kg} / \mathrm{cm}^{2}\right)$ & 3.78 & 3.95 & 4.25 & 4.23 & 0.23 & 0.070 & 0.186 \\
\hline $\operatorname{IMF}(\%)$ & 3.02 & 2.52 & 2.14 & 2.06 & 0.44 & 0.106 & 0.128 \\
\hline CIE L* & 48.36 & 46.65 & 45.51 & 45.49 & 1.35 & 0.069 & 0.053 \\
\hline CIE a* & 3.64 & 4.55 & 4.92 & 4.88 & 0.60 & 0.113 & 0.028 \\
\hline CIE b* & 10.42 & 10.82 & 10.46 & 10.59 & 0.18 & 0.969 & 0.971 \\
\hline $\mathrm{Mb}(\mathrm{mg} / \mathrm{g})$ & 0.262 & 0.363 & 0.423 & 0.434 & 0.08 & 0.055 & 0.015 \\
\hline$m b \mathrm{mRNA}^{3}$ & 1.00 & 1.22 & 1.30 & 1.29 & 0.14 & 0.116 & 0.046 \\
\hline
\end{tabular}

${ }_{1}^{1} \mathrm{pH}_{1}=$ Initial $\mathrm{pH}$ measured 45-min post-slaughter; WBC = Water binding capacity; SF = Shear force; IMF = Intramuscular fat percentage; CIE = Commission Internationale de l'E' clairage; $\mathrm{L}^{*}=$ Measurement of lightness to darkness, with a higher value indicating a lighter colour; a* = Measurement of greenness to redness, with a higher value indicating a redder colour; $b^{*}=$ Measurement of blueness to yellowness, with a higher value indicating a more yellow colour. Pen was considered as an experimental unit. Values were presented as means $(n=5)$.

${ }^{2}$ Standard error of the mean.

${ }^{3}$ The mean value in the control (CT) group was set as 1. Quantities of mRNA are normalized on the basis of gapdh expression. 
0.005). Taking into account this reduced feed conversion efficiency and the single pig from the $0.9 \mathrm{mg} / \mathrm{kg} \mathrm{Cr}$ treatment exhibiting a vomiting reaction, we think that the most appropriate dietary $\mathrm{Cr}$ supplementation level for growing-finishing pigs from 70 to $100 \mathrm{~kg}$ falls between 0.6 $\mathrm{mg} / \mathrm{kg}$ and $0.9 \mathrm{mg} / \mathrm{kg}$. Mertz (1993) concluded that the effects of $\mathrm{Cr}$ on growth performance and carcass traits are inconsistent. Previous reports suggest that $\mathrm{Cr}$ supplementation improved some aspects of growth performance (Lindemann et al., 1995; Mooney and Cromwell, 1995). Conversely, other reports indicated that Cr supplementation did not affect growth performance nor some aspects of carcass traits (Evock-Clover et al., 1993; Matthews et al., 2003). Page et al. (1993) reported that dietary $\mathrm{Cr}$ supplementation displayed a significantly cubic increase in the ADG. Evock-Clover et al. (1993) reported that young growing pigs given $\mathrm{Cr}$ showed no improvement in growth rate, feed efficiency or composition of gain. Finally, Zhang et al. (2011) reported that a supplementary dose of $0.2 \mathrm{mg} / \mathrm{kg} \mathrm{Cr}$ as chromium picolinate significantly improved daily weight gain during the finishing period, which was similar to our results. We demonstrated that dietary $\mathrm{Cr}$ supplementation increased ADG but that the feed utilization of growing-finishing pigs decreased with the increasing $\mathrm{Cr}$ supplementation. The various outcomes reported in the literature may be explained by factors such as differences in the feeding period as well as the energy concentration of the diets.

Social stress disturbs the normal immune system and endocrine system under commercial environments, thereby inducing the depression in food intake and reduced weight gain (Morrow-Tesch et al., 1994; Black et al., 2001). In vitro cellular immune response was increased in pigs fed supplemental $\mathrm{Cr}$ from $\mathrm{CrCl}_{3}$, or $\mathrm{Cr}$-picolinate and the gain and feed intake tended to improve (Van Heugten and Spears, 1997). Also, Cr supplementation benefited the immune response in weaned pigs following an LPS-induced stress by up-regulating IgG and $\gamma$-globulin levels (Lien et al., 2005). In broiler chicks, Cr supplementation can improve growth performance, carcass traits and meat lipid oxidation through alleviating the negative effects of heat stress (Toghyani et al., 2012). Stresses impaired immune function and thereby resulting in a reduction of feed intake and growth rate in weaning pigs (Van Heugten et al., 1996; Oh et al., 2010). As mentioned above, in present study, increased ADFI may attribute to the enhanced immune system and improved ability against stress by CrMet supplementation, which consequently led to the increased ADG.

\section{The effect of dietary CrMet on carcass composition}

Mooney and Cromwell (1995) reported that muscle accretion rates increased and fat accretion rates decreased with $\mathrm{Cr}$ supplementation. Additionally, carcass fat percentage and ABT decreased by $13.5 \%$ and $11.1 \%$, respectively (O'Quinn et al., 1998). Wang and Xu (2004) reported that pigs fed chromium nanoparticles had higher carcass lean meat percentages, greater loin muscle areas and lower backfat thickness. Jackson et al. (2009) reported that the addition of $\mathrm{Cr}$ decreased 10th backfat thickness and increased the percentage of muscle. Moreover, CrPic resulted in a significant reduction of $\mathrm{ABT}$ especially in castrated pigs, which was in accordance with our results (Kim et al., 2010). Previous studies elucidated that Cr partly contributed to the insulin signaling auto-amplification mechanism and thereby increasing protein accumulation via enhancing glucose utilization and regulating fat acid and fat synthesis (Vincent et al., 2000; Wong et al., 2010). Specifically, our results showed that ABT decreased linearly with the increasing dietary $\mathrm{Cr}$ supplementation, which was in agreement with previous reports (O'Quinn et al., 1998; Wang and Xu, 2004; Jackson et al., 2009). Since it is generally believed that lean red meat with less fat is beneficial to human health ( $\mathrm{Li}$ et al., 2005), and since CrMet supplementation is no higher in cost than other types of organic chromium complexes, then CrMet supplementation may be an economical means to improve the nutritional profile of pork. However, some studies have produced conflicting results. For example, dressing percentage and backfat thickness at the 10th rib and last rib did not differ between treatment groups in pigs fed CrPic (Kornegay et al., 1997). Additionally, Matthews et al. (2005) reported that loin muscle area, 10th-rib backfat thickness, ABT, dressing percentage and percent lean meat were not affected by CrProp. Such inconsistent results in terms of ABT, loin muscle area and lean meat percentage might be attributable to genetic factors, absorption ratio of different forms of $\mathrm{Cr}$, or both. These alternative factors can be clarified but it will require additional studies to examine the effect of dietary CrMet on the carcass composition with different experimental conditions.

\section{The effect of dietary CrMet on pork quality}

Reports in the literature regarding the effects of supplemental $\mathrm{Cr}$ on longissimus muscle quality have been inconsistent. Matthews et al. (2005) reported that 45-min $\mathrm{pH}$ was not affected, but that 24-h pH was higher in pigs fed CrProp. Our data agree that increasing levels of dietary Cr supplementation had no effect on 45-min pH. O'Quinn et al. (1998) reported that drip loss percentage in gilts increased with increased CrNic supplementation. Zhang et al. (2011) reported that no change occurred in water-holding capacity, which was similar to our results. The SF was impacted by several factors such as $\mathrm{pH}$, IMF and storage time of pork longissimus muscle (Van Laack et al., 2001). We found that increasing dietary $\mathrm{Cr}$ supplementation 
exerted a linear decline on SF. As shown in Table 4, the pigs in the $0.9 \mathrm{mg} / \mathrm{kg}$ and in the $0.6 \mathrm{mg} / \mathrm{kg}$ treatment groups exhibited lower IMF than those of the other treatment groups. The increased SF may be attributed to the decreased IMF induced by increased $\mathrm{Cr}$ supplementation. This may suggest that pigs have a limited capacity to maintain IMF with increasing dietary $\mathrm{Cr}$ addition, and that pork quality might be compromised by high $\mathrm{Cr}$ supplementation. Given that $\mathrm{Cr}$ addition may influence the metabolism of fat, it is plausible that $\mathrm{Cr}$ is a nutritional supplement that would affect fat deposition, including intramuscular fat deposition. In the present study, pigs fed increasing dietary $\mathrm{Cr}$ exhibited a significant quadratic effect of CIE $\mathrm{a}^{*}$, which was consistent with previous reports (Shelton et al., 2003; Zhang et al., 2011). CIE $\mathrm{a}^{*}$ increased as dietary $\mathrm{Cr}$ supplementation increased, particularly following the 0.6 and $0.9 \mathrm{mg} / \mathrm{kg} \mathrm{Cr}$ treatments, suggesting that increasing $\mathrm{Cr}$ supplementation could increase meat redness. Customers in many parts of the world prefer to purchase well-coloured pork if marbling and tenderness are no worse than medium (Norman et al., 2003; Fortomaris et al., 2006; Ngapo et al., 2007). In this case, meat colour can be regulated by dietary $\mathrm{Cr}$ and classified into several grades according to customer preference. Taken together, CrMet would be more beneficial since it is able to improve the meat colour, decrease fat percentage and increase muscle mass. Matthews et al. (2003; 2005) reported that CrProp had no effect on colour scores. The inconsistent effect might have been due to the supplementation level of dietary $\mathrm{Cr}$, which was $0.9 \mathrm{mg} / \mathrm{kg}$ in our case, compared to $0.2 \mathrm{mg} / \mathrm{kg}$ for the previous research.

\section{The effect of dietary CrMet on total Mb concentration and mRNA expression of $\boldsymbol{m b}$}

The biochemical basis of red colour in meats is well established and depends on the concentration and redox state of Mb, haemoglobin and cytochromes in meat. Due to the exposure to oxygenic environment during exsanguinations, most of the muscle haemoglobin is lost and ultimately accounts for between $6 \%$ and $16 \%$ of total fresh meat pigment. $\mathrm{Cr}$ supplementation improved antioxidative ability and attenuated oxidative stress in broilers and rats (Rama Rao et al., 2012; Sundaram et al., 2012). Mb is the primary protein pigment responsible for meat colour and constitutes between $80 \%$ and $90 \%$ of total fresh meat pigment (Giddings and Solberg, 1977). Thus, the total Mb concentration in the longissimus muscle of the pig is a very important contributor to pork colour. $\mathrm{Cr}$ is essential for normal glucose metabolism, functioning as a part of the insulin signaling auto-amplification mechanism and improves insulin-stimulated amino acid uptake and protein synthesis and gene expression (Vincent et al., 2000; Peng et al., 2010). The present results showed the CIE $a^{*}$ increased linearly with increasing total Mb content. Quantitative realtime PCR was used to analyze differentially expressed proteins at the mRNA level, which revealed a positive correlation between the content of the $\mathrm{Mb}$ and the mRNA levels. CrMet influenced total $\mathrm{Mb}$ content and the expression levels of $m b$ suggesting that $\mathrm{Cr}$ has a doserelated effect on $\mathrm{Mb}$ synthesis activity by regulating the transcription of $m b$. Zhang et al. (2011) reported that RNA/DNA increased significantly, while the content of DNA in skeletal muscle showed no marked changes with CrPic supplementation. Therefore, on the basis of these results, we hypothesize that dietary $\mathrm{Cr}$ supplementation may have improved anti-oxidative status and stimulated the mRNA expression level of the $m b$ gene and Mb synthesis, which promoted $\mathrm{Mb}$ protein synthesis and improved the meat colour. However, no significant difference in $\mathrm{mb}$ mRNA expression existed among treatments in the five pigs per treatment that were analyzed. This may imply that the threshold of effect for $\mathrm{Cr}$ on $m b$ mRNA may fall below the levels we tested. The effect of dietary CrMet on local $\mathrm{mb}$ mRNA abundance therefore needs further study.

\section{CONCLUSIONS}

CrMet, as a highly bioavailable complex, has lesser environmental hazards and would be more beneficial since it is able to improve the meat colour, decrease fat percentage and increase muscle. If some regulatory agencies could alleviate the negative effects of SF and IMF, then CrMet may become an economical means to improve meat quality and it then would be wise for pig producers to add CrMet to the diets. However, considering previous inconsistent studies and the small number of pigs analyzed in the present study, the effect of CrMet on growingfinishing pigs needs further confirmation.

\section{ACKNOWLEDGEMENTS}

We are grateful to the Changzhou Yongkang Agricultural and Animal Husbandry Technology Co., Ltd for providing the experimental animals and the Changsha HingKa Biological Engineering Co., Ltd for chromium methionine. This study was partly supported by a research fund for the National Nature Science Foundation of China (No. 31172206), Key Programs for Science and Technology Development of Jiangsu Province (BE2009330-1) and Jiangsu Agricultural Three New Engineering Program (SXGC[2012]393).

\section{REFERENCES}

AOAC. 1997. Official methods of analysis. 16th ed. Association of Official Analytical Chemists, Arlington, VA. 
Black, J. L., L. R. Giles, P. C. Wynn, A. G. Knowles, C. A. Kerr, M. R. Jones, A. D. Strom, N. L. Gallagher, and G. J. Eamens. 2001. Factors limiting the performance of growing pigs in commercial environments. In Manipulating pig production VIII (P. D. Cranwell) pp. 25-28. APSA, Adelaide, Australia.

Evock-Clover, C. M., M. M. Polansky, R. A. Anderson, and N. C. Steele. 1993. Dietary chromium supplementation with or without somatotropin treatment alters serum hormones and metabolites in growing pigs without affecting growth performance. J. Nutr. 123:1504-1512.

Fortomaris, P., G. Arsenos, M. Georgiadis, G. Banos, C. Stamataris, and D. Zygoyiannis. 2006. Effect of meat appearance on consumer preferences for pork chops in Greece and Cyprus. Meat Sci. 72:688-696.

Gandolfi, G., L. Pomponio, P. Ertbjerg, A. H. Karlsson, L. N. Costa, R. Lametsch, V. Russo, and R. Davoli. 2011. Investigation on CAST, CAPN1 and CAPN3 porcine gene polymorphisms and expression in relation to post-mortem calpain activity in muscle and meat quality. Meat Sci. 88:694700 .

Giddings, G. G., and M. Solberg. 1977. The basis of color in muscle foods. Crit. Rev. Food Sci. Nutr. 9:81-114.

Gu, Y., A. P. Schinckel, J. C. Forrest, C. H. Kuei, and L. E. Watkins. 1991. Effects of ractopamine, genotype, and growth phase on finishing performance and carcass value in swine: II. Estimation of lean growth rate and lean feed efficiency. J. Anim. Sci. 69:2694-2702.

Haldar, S., S. Mondal, S. Samanta, and T. K. Ghosh. 2009. Effects of dietary chromium supplementation on glucose tolerance and primary antibody response against peste des petits ruminants in dwarf Bengal goats ( Capra hircus). Animal 3:209-217.

Hoek, A. C., M. A. J. S. Boekel, J. Voordouw, and P. A. Luning. 2011. Identification of new food alternatives: How do consumers categorize meat and meat substitutes? Food Qual. Prefer. 22:371-383.

Honikel, K. O. 1998. Reference methods for the assessment of physical characteristics of meat. Meat Sci. 49:447-457.

Hunt, M. C., R. A. Mancini, K. A. Hachmeister, D. H. Kropf, M. Merriman, G. DelDuca, and G. Milliken. 2004. Carbon monoxide in modified atmosphere packaging affects color, shelf life, and microorganisms of beef steaks and ground beef. J. Food Sci. 69:C45-C52.

Jackson, A. R., S. Powell, S. L. Johnston, J. O. Matthews, T. D. Bidner, F. R. Valdez, and L. L. Southern. 2009. The effect of chromium as chromium propionate on growth performance, carcass traits, meat quality, and the fatty acid profile of fat from pigs fed no supplemented dietary fat, choice white grease, or tallow. J. Anim. Sci. 87:4032-4041.

Kim, B. G., M. D. Lindemann, and G. L. Cromwell. 2010. Effects of dietary chromium (III) picolinate on growth performance, respiratory rate, plasma variables, and carcass traits of pigs fed high-fat diets. Biol. Trace Elem. Res. 133:181-196.

Kornegay, E. T., Z. Wang, C. M. Wood, and M. D. Lindemann. 1997. Supplemental chromium picolinate influences nitrogen balance, dry matter digestibility, and carcass traits in growingfinishing pigs. J. Anim. Sci. 75:1319-1323.

Krzysik, M., H. Grajeta, A. Prescha, and R. Weber. 2011. Effect of cellulose, pectin and chromium(III) on lipid and carbohydrate metabolism in rats. J. Trace Elem. Med. Biol. 25:97-102.
Krzywicki, K. 1982. The determination of haem pigments in meat. Meat Sci. 7:29-36.

Li, D., S. Siriamornpun, M. L. Wahlqvist, N. J. Mann, and A. J. Sinclair. 2005. Lean meat and heart health. Asia Pac. J. Clin. Nutr. 14:113-119.

Lien, T. F., K. H. Yang, and K. J. Lin. 2005. Effect of chromium propionate supplementation on growth performance, serum traits and immune response in weaned pigs. Asian-Aust. J. Anim. Sci. 18:403-408.

Lindemann, M. D., C. M. Wood, A. F. Harper, E. T. Kornegay, and R. A. Anderson. 1995. Dietary chromium picolinate additions improve gain:feed and carcass characteristics in growingfinishing pigs and increase litter size in reproducing sows. J. Anim. Sci. 73:457-465.

Livak, K. J., and T. D. Schmittgen. 2001. Analysis of relative gene expression data using real-time quantitative PCR and the $2^{-\Delta \Delta \mathrm{Ct}}$ method. Methods 25:402-408.

Mancini, R. A., and M. C. Hunt. 2005. Current research in meat color. Meat Sci. 71:100-121.

Mason, L. M., S. A. Hogan, A. Lynch, K. O'Sullivan, P. G. Lawlor, and J. P. Kerry. 2005. Effects of restricted feeding and antioxidant supplementation on pig performance and quality characteristics of longissimus dorsi muscle from Landrace and Duroc pigs. Meat Sci. 70:307-317.

Matthews, J. O., A. C. Guzik, F. M. Lemieux, L. L. Southern, and T. D. Bidner. 2005. Effects of chromium propionate on growth, carcass traits, and pork quality of growing-finishing pigs. J. Anim. Sci. 83:858-862.

Matthews, J. O., A. D. Higbie, L. L. Southern, D. F. Coombs, T. D. Bidner, and R. L. Odgaard. 2003. Effect of chromium propionate and metabolizable energy on growth, carcass traits, and pork quality of growing-finishing pigs. J. Anim. Sci. 81:191-196.

Mertz, W. 1993. Chromium in human nutrition: a review. J. Nutr. 123:626-633.

Mooney, K. W., and G. L. Cromwell. 1995. Effects of dietary chromium picolinate supplementation on growth, carcass characteristics, and accretion rates of carcass tissues in growing-finishing swine. J. Anim. Sci. 73:3351-3357.

Morrow-Tesch, J. L., J. J. McGlone, and J. L. Salak-Johnson. 1994. Heat and social stress effects on pig immune measures. J. Anim. Sci. 72:2599-2609.

Ngapo, T. M., J. F. Martin, and E. Dransfield. 2007. International preferences for pork appearance: II. Factors influencing consumer choice. Food Qual. Prefer. 18:139-151.

Norman, J. L., E. P. Berg, H. Heymann, and C. L. Lorenzen. 2003. Pork loin color relative to sensory and instrumental tenderness and consumer acceptance. Meat Sci. 65:927-933.

NPPC. 2000. Pork composition and quality assessment procedures. 1st ed. National Pork Council, Des Moines, IA.

O'Quinn, P. R., J. W. Smith, J. L. Nelssen, M. D. Tokach, R. D. Goodband, K. Q. Owen, and S. A. Blum. 1998. Effects of source and level of added chromium on growth performance and carcass characteristics of growing-finishing pigs. J. Anim. Sci. 76 (Suppl.2):125 (Abstr.).

Oh, H. K., H. B. Choi, W. S. Ju, C. S. Chung, and Y. Y. Kim. 2010. Effects of space allocation on growth performance and immune system in weaning pigs. Livest. Sci. 132:113-118.

Ohh, S. J., and J. Y. Lee. 2005. Dietary chromium-methionine 
chelate supplementation and animal performance. Asian-Aust. J. Anim. Sci. 18:898-907.

Padmavathi, I. J., K. R. Rao, L. Venu, A. Ismail, and M Raghunath. 2010. Maternal dietary chromium restriction programs muscle development and function in the rat offspring. Exp. Biol. Med. 235:349-355.

Page, T. G., L. L. Southern, T. L. Ward, and D. L. Thompson, Jr. 1993. Effect of chromium picolinate on growth and serum and carcass traits of growing-finishing pigs. J. Anim. Sci. 71:656662.

Peng, Z., W. Qiao, Z. Wang, Q. Dai, J. He, C. Guo, J. Xu, and A. Zhou. 2010. Chromium improves protein deposition through regulating the mRNA levels of IGF-1, IGF-1R and Ub in rat skeletal muscle cells. Biol. Trace Elem. Res. 137:226-234.

Rama Rao, S. V., M. V. L. N. Raju, A. K. Panda, N. S. Poonam, O. Krishna Murthy, and G. Shyam Sunder. 2012. Organic chromium on performance, carcass traits, oxidative parameters and immune responses in commercial broiler chickens. Biol. Trace Elem. Res. 147:135-141.

Shelton, J. L., R. L. Payne, S. L. Johnston, T. D. Bidner, L. L. Southern, R. L. Odgaard, and T. G. Page. 2003. Effect of chromium propionate on growth, carcass traits, pork quality, and plasma metabolites in growing-finishing pigs. J. Anim. Sci. 81:2515-2524.

Sundaram, B., A. Aggarwal, and R. Sandhir. 2012. Chromium picolinate attenuates hyperglycemia-induced oxidative stress in streptozotocin-induced diabetic rats. J. Trace Elem. Med. Bio. 27:117-121.

Toghyani, M., M. Toghyani, M. Shivazad, A. Gheisari, and R. Bahadoran. 2012. Chromium supplementation can alleviate the negative effects of heat stress on growth performance, carcass traits and meat lipid oxidation of broiler chicks without any adverse impacts on blood constituents. Biol. Trace Elem. Res. 146:171-180.
Van Heugten, E. V., M. T. Coffey, and J. W. Spears. 1996. Effects of immune challenge, dietary energy density and source of energy on performance and immunity in weanling pigs. J. Anim. Sci. 74:2431-2440.

Van Heugten, E. V., and J. W. Spears. 1997. Immune reponse and growth of stressed weanling pigs fed diets supplemented with organic or inorganic forms of chromium. J. Anim. Sci. 75: 409-416.

Van Laack, R. L., S. G. Stevens, and K. J. Stalder. 2001. The influence of ultimate $\mathrm{pH}$ and intramuscular fat content on pork tenderness and tenderization. J. Anim. Sci. 79:392-397.

Vincent, J. B. 2000. The biochemistry of chromium. J. Nutr. 130: 715-718.

Wagner, J. R., A. P. Schinckel, W. Chen, J. C. Forrest, and B. L. Coe. 1999. Analysis of body composition changes of swine during growth and development. J. Anim. Sci. 77:1442-1466.

Wallace, W. J., R. A. Houtchens, J. C. Maxwell, and W. S. Caughey. 1982. Mechanism of autooxidation for hemoglobins and myoglobins. Promotion of superoxide production by protons and anions. J. Biol. Chem. 257:4966-4977.

Wang, M. Q., and Z. R. Xu. 2004. Effect of chromium nanoparticle on growth performance, carcass characteristics, pork quality and tissue chromium in finishing pigs. Asian-Aust. J. Anim. Sci. 17:1118-1122.

Wong, R. H. F., and H. S. Sul. 2010. Insulin signaling in fatty synthesis: a transcription perspective. Curr. Opin. Pharmacol. 10:684-691.

Zhang, H. B., B. J. Dong, M. H. Zhang, and J. J. Yang. 2011. Effect of chromium picolinate supplementation on growth performance and meat characteristics of swine. Biol. Trace Elem. Res. 141:159-169. 